\title{
Production and characterization of a biosurfactant produced by Streptomyces sp. DPUA 1559 isolated from lichens of the Amazon region
}

\author{
A.P.P. Santos ${ }^{1}$, M.D.S. Silva ${ }^{1}$, E.V.L. Costa ${ }^{1}$, R.D. Rufino ${ }^{3}$, V.A. Santos $^{3}$, C.S. Ramos ${ }^{2}$, \\ L.A. Sarubbo ${ }^{3}$ and A.L.F. Porto ${ }^{1}$ \\ ${ }^{1}$ Departamento de Morfologia e Fisiologia Animal, Universidade Federal Rural de Pernambuco, Recife, PE, Brasil \\ ${ }^{2}$ Departamento de Química, Universidade Federal Rural de Pernambuco, Recife, PE, Brasil \\ ${ }^{3}$ Centro de Ciências e Tecnologia, Universidade Católica de Pernambuco, Recife, PE, Brasil
}

\begin{abstract}
Surfactants are amphipathic compounds containing both hydrophilic and hydrophobic groups, capable to lower the surface or interfacial tension. Considering the advantages of the use of biosurfactants produced by microorganisms, the aim of this paper was to develop and characterize a biosurfactant produced by Streptomyces sp. DPUA1559 isolated from lichens of the Amazon region. The microorganism was cultured in a mineral medium containing $1 \%$ residual frying soybean oil as the carbon source. The kinetics of biosurfactant production was accompanied by reducing the surface tension of the culture medium from 60 to values around $27.14 \mathrm{mN} / \mathrm{m}$, and by the emulsification index, which showed the efficiency of the biosurfactant as an emulsifier of hydrophobic compounds. The yield of the isolated biosurfactant was $1.74 \mathrm{~g} / \mathrm{L}$, in addition to the excellent capability of reducing the surface tension $(25.34 \mathrm{mN} / \mathrm{m})$, as observed from the central composite rotational design when the biosurfactant was produced at $\mathrm{pH} 8.5$ at $28^{\circ} \mathrm{C}$. The critical micelle concentration of the biosurfactant was determined as $0.01 \mathrm{~g} / \mathrm{mL}$. The biosurfactant showed thermal and $\mathrm{pH}$ stability regarding the surface tension reduction, and tolerance under high salt concentrations. The isolated biosurfactant showed no toxicity to the micro-crustacean Artemia salina, and to the seeds of lettuce (Lactuca sativa L.) and cabbage (Brassica oleracea L.). The biochemistry characterization of the biosurfactant showed a single protein band, an acid character and a molecular weight around $14.3 \mathrm{kDa}$, suggesting its glycoproteic nature. The results are promising for the industrial application of this new biosurfactant.
\end{abstract}

Key words: Biosurfactant; Surface tension; Emulsification; Streptomyces; Soybean frying oil

\section{Introduction}

Surfactants are substances widely utilized for cleaning in general, removing undesirable particles or dirtiness by a process called emulsification. Surfactants are amphipathic compounds, containing both hydrophilic (polar) and hydrophobic (nonpolar) groups, capable to lower the surface or interfacial tension between two liquid phases such as oil/water, or air/liquid interfaces (1-3). One of the surfactants widely used in personal care products is the sodium lauryl sulfate. This anionic surfactant is synthesized by reacting lauryl alcohol from a petroleum or plant source with sulfur trioxide (4). The surfactants of biological origin produced by microorganisms (bacteria, yeasts and fungi) are known as biosurfactants (2). The biosurfactants can also be produced by animals; for instance, the type II alveolar epithelial cells (pneumocytes) can synthesize a surface-active phospholipoprotein which is the pulmonary surfactant (5). Biosurfactants are classified based on their chemical structures that include glycolipids, lipopeptides, polysaccharide-protein complexes, phospholipids, fatty acids and neutral lipids (3). Moreover, surfactants can be classified according to the ionization state in aqueous solution as anionic (functional group with negative charge), cationic (functional group with positive charge), nonionic (no charge that influences the aqueous medium, so they do not ionize in aqueous solution) and amphoteric (anionic and cationic characteristic) (6).

In addition to the surface-active properties, biosurfactants produced by some microorganisms have exhibited antimicrobial activity and anti-adhesive activity against several other microorganisms $(3,7)$.

The biosurfactants have attracted attention because of their low toxicity, biodegradability, and ecological acceptability; 
furthermore, low cost raw materials, such as agricultural and industrial waste can be used as substrates to the biosurfactant production (1).

The properties of biosurfactants allow their utility in various areas of applications such as bioremediation, biodegradation, enhanced oil recovery, pharmaceutics, food processing among many others $(7,8)$.

Over the last few years, species of the genus Streptomyces have been used to produce biosurfactants, especially the bacteria of the Actinomycetes group. These bacteria have a filamentous organization, are aerobic, catalase-positive and can inhabit the soil. They are microorganisms of interest for medical, agricultural and biotechnology areas, since most of the strains synthesize antibacterial, antifungal, antitumor, antiparasitic substances, herbicides and enzymes $(7,9,10)$.

Considering the advantages of biosurfactants produced by microorganisms, the aim of this paper was to perform the production and the characterization of a new biosurfactant produced by Streptomyces $s p$. DPUA1559 isolated from lichens of the Amazon region.

\section{Material and Methods}

\section{Bacterial strain and preparation of seed culture}

A strain of Streptomyces sp DPUA1559 isolated from lichens of the Amazon region, belonging to the collection of the Departamento de Parasitologia, Universidade Federal do Amazonas (Manaus, AM, Brazil) was used. Sporulated cultures were obtained in Petri dishes with ISP-2 solid medium. The medium was composed of $0.4 \%(\mathrm{v} / \mathrm{v})$ yeast extract, $1 \%(\mathrm{v} / \mathrm{v})$ malt extract and $2 \%(\mathrm{v} / \mathrm{v})$ agar, $\mathrm{pH} 7.0$, and it was incubated in a bacteriological incubator for 15 days at $30^{\circ} \mathrm{C}$. The stock culture was kept in cryotubes with $10 \%(\mathrm{v} / \mathrm{v})$ glycerol, under cooling at $-18^{\circ} \mathrm{C}$. The microorganism was activated in ISP-2 medium, modified by the absence of glucose according to Pridham et al. (11). The inoculum was obtained after culture in $1.0 \%(\mathrm{v} / \mathrm{v})$ malt extract and $0.4 \%(\mathrm{v} / \mathrm{v})$ yeast extract. The $\mathrm{pH}$ of the medium was adjusted to 7.0 with $1 \mathrm{M} \mathrm{NaOH}$, and it was fermented on an orbital shaker (B. Braun Melsungen AG) under $150 \mathrm{rpm}$ at $28^{\circ} \mathrm{C}$ for $48 \mathrm{~h}$.

\section{Fermentation medium and biosurfactant production}

Soybean frying oil was used as the carbon source to produce the biosurfactant. The fermentation medium consisted of $10 \mathrm{~g} / \mathrm{L}$ soybean residual oil, $10 \mathrm{~g} / \mathrm{L} 1 \%$ peptone, $4.75 \mathrm{~g} / \mathrm{L} \mathrm{K}_{2} \mathrm{HPO}_{4}, 1 \mathrm{~g} / \mathrm{L} \mathrm{NH}_{4} \mathrm{Cl}, 6 \mathrm{~g} / \mathrm{L} \mathrm{MgSO}{ }_{4} .7 \mathrm{H}_{2} \mathrm{O}$, and $1 \mathrm{~mL}$ of nutrient solution (100 mg FeSO ${ }_{4} \cdot 7 \mathrm{H}_{2} \mathrm{O}, 100 \mathrm{mg} \mathrm{MnCl} 2$. $4 \mathrm{H}_{2} \mathrm{O}, 100 \mathrm{mg} \mathrm{ZnSO}{ }_{4} \cdot \mathrm{H}_{2} \mathrm{O}$, and $100 \mathrm{mg}$ of $\mathrm{CaCl}_{2} \cdot \mathrm{H}_{2} \mathrm{O}$ ), adjusted to $\mathrm{pH} 7.5$ with a solution of $1 \mathrm{M} \mathrm{NaOH}$.

The biosurfactant production was conducted in Erlenmeyer flasks $(250 \mathrm{~mL})$ containing $50 \mathrm{~mL}$ of the fermentation medium inoculated with $10^{8} \mathrm{CFU} / \mathrm{mL}$ aliquots of each conical spore in an orbital shaker (B. Braun Melsungen $A G)$ at $200 \mathrm{rpm}, 28^{\circ} \mathrm{C}$ for $96 \mathrm{~h}$.

\section{Experimental design through central composite rotatable design (CCRD)}

A CCRD was used to determine the effects and interactions of two factors for biosurfactant production by Streptomyces sp. DPUA1559. Temperature and $\mathrm{pH}$ were the independent variables. Surface tension was the response variable. In this design, a set of 12 experiments was performed, with four replicates at the central points. The statistical analysis of the four replicates gives an indication of the experimental error of the production technique. The range and levels of the components (factors or independent variables) are given in Table 1. Each factor in the design was studied on five levels $(-1.41,-1.0,0,+1$, and +1.41$)$, with zero as the central coded value. Analysis of variance (ANOVA) with 95\% confidence intervals was used to determine the significance of the effects. ANOVA, the determination of regression coefficients and the construction of graphs were performed with the aid of the Statistica ${ }^{\circledR}$ program, version 12.0 (USA).

\section{Growth kinetics and biosurfactant production}

To determine the growth kinetics, samples were collected every $4 \mathrm{~h}$ during the first $12 \mathrm{~h}$, then every $12 \mathrm{~h}$ until $120 \mathrm{~h}$ of fermentation. The samples were subjected to biomass analysis, determination of $\mathrm{pH}$, surface tension and emulsification index measurements.

\section{Biomass determination}

For biomass determination, $10 \mathrm{~mL}$ samples were centrifuged at $5000 \mathrm{~g}$ for $30 \mathrm{~min}$ at $5^{\circ} \mathrm{C}$ and the cell pellet was dried in an oven at $105^{\circ} \mathrm{C}$ for $24 \mathrm{~h}$.

\section{Isolation of biosurfactant}

The biosurfactant was extracted from culture media after cell removal by centrifugation at $5000 \mathrm{~g}$ for $30 \mathrm{~min}$ at $5^{\circ} \mathrm{C}$. The supernatant $\mathrm{pH}$ was adjusted to 2.0 with $6.0 \mathrm{M}$ $\mathrm{HCl}$, and an equal volume of $\mathrm{CHCl}_{3} / \mathrm{CH}_{3} \mathrm{OH}$ (2:1) was added. The mixture was vigorously shaken for $15 \mathrm{~min}$ and allowed to set until phase separation according to Javaheri et al. (12). After phase separation, the concentrate was centrifuged at $3000 \mathrm{~g}$ for $5 \mathrm{~min}$ at $5^{\circ} \mathrm{C}$ and suspended in Milli-Q water. Then the concentrate was added to a sterile petri dish and neutralized with $1 \mathrm{M}$ $\mathrm{NaOH}$ solution to $\mathrm{pH} 7.0$. It was then preserved in a drying oven at $37^{\circ} \mathrm{C}$ for $12 \mathrm{~h}$. The yield of biosurfactant was

Table 1. Real and coded values of the variables for the central composite rotational design.

\begin{tabular}{lcrrrc}
\hline Factors & -1.41 & \multicolumn{1}{c}{-1} & \multicolumn{1}{c}{0} & \multicolumn{1}{c}{1} & 1.41 \\
\hline $\mathrm{pH}$ & 8.36 & 8.4 & 8.5 & 8.6 & 8.64 \\
Temperature ${ }^{\circ} \mathrm{C}$ & 26.6 & 27.0 & 28.0 & 29.0 & 29.4 \\
\hline
\end{tabular}

$\mathrm{pH}:\left(\mathrm{X}_{1}\right)$; Temperature ${ }^{\circ} \mathrm{C}:\left(\mathrm{X}_{2}\right)$. 
obtained in $\mathrm{g} / \mathrm{L}$ and used to measure the critical micelle concentration (CMC).

\section{Emulsification index with different hydrophobic compounds}

The rate of emulsification was measured using the method described by Cooper and Goldenberg (13). The cell-free fermentation broth was mixed to one of the following hydrophobic compounds (in ratio 1:1, v/v): kerosene, motor oil, residual motor oil, diesel oil, corn oil, canola oil, soybean oil or sunflower oil. The mixture was homogenized in a vortex for $2 \mathrm{~min}$ at room temperature. The emulsion stability was determined after $24 \mathrm{~h}$. The emulsification index was calculated as the ratio between the height of emulsifying layer and the total height, being the value obtained multiplied by 100 .

\section{Stability studies}

The effect of environmental factors on biosurfactant activity was determined according to Rufino et al. (8). The effect of addition of different concentrations of $\mathrm{NaCl}$ on the activity of the biosurfactant was investigated in the cellfree broth. A specific concentration of $\mathrm{NaCl}(2-10 \%$, w/v) was added and surface tension was determined as previously stated. The cell-free broth was also maintained at a constant temperature $\left(4,28,70,100\right.$, and $\left.120^{\circ} \mathrm{C}\right)$ for $60 \mathrm{~min}$ and used for surface tension measurement. The effect of $\mathrm{pH}$ on surface tension was evaluated after adjustment of the broth $\mathrm{pH}$ to 2, 4, 6, 8, 10, and 12 with 6.0 $\mathrm{M} \mathrm{NaOH}$ or $\mathrm{HCl}$.

\section{Determination of surface tension and CMC of the biosurfactant}

The surface tension was determined using a Sigma 700 tensiometer (KSV Instruments Ltd., Finland). The surface tension of Milli-Q water $(72 \mathrm{mN} / \mathrm{m})$ was used to calibrate the tensiometer. The measurements of surface tension were performed using the Du Noüy ring method. The analysis of surface tension were performed in triplicate on cell-free broth obtained by centrifuging the culture medium. CMC was determined by the surface tension obtained from frequent dilutions of the biosurfactant in Milli-Q water, until it reached a maximum surface tension in relation to concentration of surfactant molecules. The result of the CMC was obtained after stabilization of the concentration.

\section{Determination of biosurfactant toxicity}

The lethality test with the brine shrimp was performed according to the method described by Meyer et al. (14). The biological assay was performed using the microcrustacean Artemia salina incubated in $30 \mathrm{~g} / \mathrm{L}$ of sea salt solution diluted in distilled water under $28^{\circ} \mathrm{C}$ at $\mathrm{pH} 8.0$. Samples were processed in triplicate after $24 \mathrm{~h}$ incubation of larvae in a test containing 10 micro-crustacean $A$. salina in $5 \mathrm{~mL}$ per tube of solution. The following concentrations were used: $50,100,150,300,400,500$, and $600 \mathrm{mg} / \mathrm{mL}$ using the biosurfactant at the CMC and kept under artificial light. The calculation of nauplii mortality rate was carried out after $24 \mathrm{~h}$. Mortality data were submitted to Probit analysis and lethal concentrations estimated using the POLO-PC software (LeOra Software Company, USA).

The phytotoxicity test was used to investigate the action of the biosurfactant on lettuce seeds (Lactuca sativa L.) and cabbage seeds (Brassica oleracea L.) (15). The disinfected seeds were placed in Petri plate on sterile filter paper and $5 \mathrm{~mL}$ of the isolated biosurfactant at the CMC in concentrations of 1,5 , and $50 \mathrm{mg} / \mathrm{mL}$ were added.

The determination was done after $120 \mathrm{~h}$ on the seed germination relative to root length and germination rate of the seeds, as follows: relative seed germination $(\%)=$ (number of seeds germinated in the extract/number of seeds germinated in control) $\times 100$; relative root length $(\%)=($ mean root length in the extract/mean root length in the control) $\times 100 ;$ germination index $=[(\%$ of seed germination $) \times(\%$ of root growth $)] / 100 \%$.

\section{Chemical composition of the biosurfactant}

The protein concentration of the isolated biosurfactant was determined by the method of Lowry (16), using bovine serum albumin as standard. The carbohydrate content was determined by the method of phenol-sulfuric acid according to Dubois et al. (17) using D-glucose as a standard, while the total lipid content was measured by the method described by Folch et al. (18).

\section{Polyacrylamide gel electrophoresis}

The molecular characterization of the proteins was carried out in polyacrylamide gel $(12 \% \mathrm{w} / \mathrm{v})$ under denaturing condition in the presence of sodium lauryl sulfate (SDS) and under reducing condition in the presence of 2-mercaptoethanol, according to the method described by Laemmli (19). Protein electrophoresis under acidic condition was performed according to Davis (20). The protein bands were subjected to staining with Coomassie Blue R-250, silver staining and Schiff staining. Bovine serum albumin (66 kDa), egg white albumin (45 kDa), carbonic anhydrase $(29 \mathrm{kDa})$ and lysozyme $(14.3 \mathrm{kDa})$ were used as molecular weight markers (Sigma-Aldrich, USA).

\section{Fourier transform infrared spectroscopy (FTIR)}

To determine the infrared spectrum of the major functional groups of the isolated biosurfactant from Streptomyces sp. DPUA1559, it was submitted to a serial solubility test in different solvents in the ratio $1: 1$ $(\mathrm{v} / \mathrm{v})$, alternating the polarity of the solvents: hexane, dichloromethane, methanol, ethyl acetate and distilled water. The sample was analyzed by attenuated total reflection (ATR) technique in FTIR (ATR-FTIR). The spectrum was generated in the wavelength range of 4000 to $400 \mathrm{~cm}^{-1}$ using a Varian 640 IR FTIR spectrometer (Varian, Australia). 


\section{Results and Discussion}

\section{Experimental design through CCRD}

A proper experimental design is based on the number of factors to be studied. The planning matrix obtained for the CCRD is shown in Table 2, where the variables ( $\mathrm{pH}$ and temperature) in response to surface tension are presented.

Surface tension values pass through a central point indicating that the studied interval was suitable, when the surface tension reduction was used as a primary criterion for the production of the biosurfactant.

The CCRD was used to determine the production conditions of the surfactant agent from Streptomyces $s p$. DPUA1559 using ANOVA (Table 3). Parameters as experimental error, lack of fit, Fisher constant $(F)$ and value of confidence level $(p)$ are the main criteria for obtaining a statistical prediction model.

The ANOVA indicates that the linear terms of temperature $\left(\mathrm{X}_{2}\right)\left(\mathrm{X}_{2}\right)$ and quadratic term of $\mathrm{pH}$ and temperature

Table 2. Planning matrix for central composite rotational design of experimental data for the biosurfactant produced by Streptomyces sp. DPUA1559 in culture medium after 96 h. $\mathrm{pH}:\left(\mathrm{X}_{1}\right)$; temperature ${ }^{\circ} \mathrm{C}$ : $\left(\mathrm{X}_{2}\right)$; surface tension $-\mathrm{mN} / \mathrm{m}$ : $(\mathrm{Y})$.

\begin{tabular}{lccc}
\hline Assay & $\mathrm{pH}$ & Temperature $\left({ }^{\circ} \mathrm{C}\right)$ & Surface tension $(\mathrm{mN} / \mathrm{m})$ \\
\hline 1 & 8.40 & 27.0 & 30.40 \\
2 & 8.40 & 29.0 & 28.00 \\
3 & 8.60 & 27.0 & 29.38 \\
4 & 8.60 & 29.0 & 27.47 \\
5 & 8.36 & 28.0 & 30.73 \\
6 & 8.64 & 28.0 & 28.85 \\
7 & 8.50 & 26.6 & 28.68 \\
8 & 8.50 & 29.4 & 26.95 \\
9 & 8.50 & 28.0 & 25.47 \\
10 & 8.50 & 28.0 & 25.96 \\
11 & 8.50 & 28.0 & 25.59 \\
12 & 8.50 & 28.0 & 24.34 \\
\hline
\end{tabular}

are statistically significant, since the constant critical value of Fisher for these terms is less than the respective calculated values. This statistical significance is also observed when the respective values of confidence level were less than $0.05(\mathrm{P}<0.05)$. The linear terms of $\mathrm{pH}$ and the interaction between $\mathrm{pH}$ and temperature did not have statistical significance for the prediction model. The fit of the model and the relatively small value of the experimental error ensure that a good prediction model was obtained.

Figure 1 shows the Pareto diagram of the experimental assays, confirming what was observed through ANOVA (Table 3). The diagram indicates that the $\mathrm{pH}$ quadratic term is the most statistically significant term, followed in descending order by the quadratic term of temperature and linear term of temperature.

Thus, only the individual values used were effective in lowering the surface tension. After these graphical and numerical analysis, a statistical prediction model was established for the operating range covered by the limits used in the CCRD. Therefore, to predict the surface tension, there is a model based on the regression coefficients obtained with the help of Table 1 (Equation 1):

$$
Y=17653-81.1 X_{2}+225.5 X_{1}^{2}+1.25 X_{2}^{2}
$$

The microorganism demonstrated great conditions for biosurfactant production in the temperature range 28 to $30^{\circ} \mathrm{C}$ for $96 \mathrm{~h}$, evaluated with the soybean frying oil as the sole carbon source. The microorganism was able to reduce the surface tension of the medium in all assays.

The biosurfactant production was accompanied by surface tension measurements in the culture medium, which value decreased from 60 to $27.14 \mathrm{mN} / \mathrm{m}$. The surface tension of the biosurfactant produced by Streptomyces $s p$. DPUA1559 were lower than the values of the surfactant produced by Bacillus subtilis, as reported by Mulligan (21) who observed a reduction of the surface tension to $27 \mathrm{mN} / \mathrm{m}$. Lima e Silva et al. (22) showed that the surfactant from Pseudomonas fluoresces UCP1514 presented a surface tension of $31.68 \mathrm{mN} / \mathrm{m}$ when produced in corn steep liquor

Table 3. ANOVA for the surface tension of the biosurfactant produced by Streptomyces $s p$. DPUA1559 in mineral medium containing $1 \%$ residual soybean oil after $96 \mathrm{~h}$ of fermentation.

\begin{tabular}{lrrrrr}
\hline Factor & Quadratic sum & Degrees of freedom & Quadratic mean & \multicolumn{1}{c}{$\mathrm{F}$} & $\mathrm{P}$ \\
\hline $\mathrm{X}_{1}$ & 2.22539 & 1 & 2.22539 & 4.59995 & 0.121308 \\
$\mathrm{X}_{1}^{2}$ & 31.74989 & 1 & 31.74989 & 65.62788 & 0.003931 \\
$\mathrm{X}_{2}$ & 5.67020 & 1 & 5.67020 & 11.72046 & 0.041735 \\
$\mathrm{X}_{2}^{2} \mathrm{X}_{2}$ & 9.85354 & 1 & 9.85354 & 20.36753 & 0.020332 \\
$\mathrm{X}_{1} * \mathrm{X}_{2}$ & 0.05978 & 1 & 0.05978 & 0.12357 & 0.748437 \\
Lack of fit & 0.58603 & 3 & 0.19534 & 0.40378 & 0.762023 \\
Experimental error & 1.45136 & 3 & 0.48379 & & \\
Total & 45.95987 & 11 & & & \\
\hline
\end{tabular}

$\mathrm{X}_{1}: \mathrm{pH} ; \mathrm{X}_{1}^{2}$ : quadratic term of $\mathrm{pH} ; \mathrm{X}_{2}$ : temperature $\left({ }^{\circ} \mathrm{C}\right) ; \mathrm{X}_{2}^{2}$ : quadratic term of temperature ${ }^{\circ} \mathrm{C} ; \mathrm{X}_{1} * \mathrm{X}_{2}$ : quadratic term of $\mathrm{pH}$ and temperature ${ }^{\circ} \mathrm{C} ; \mathrm{R}^{2}: 0.9557 ; \mathrm{R}: 0.9187 ; \mathrm{F}$ and $\mathrm{P}$ value in ANOVA test, where $\mathrm{F}_{\text {critical }}=10.12 \mathrm{X}_{1}^{2}$. 


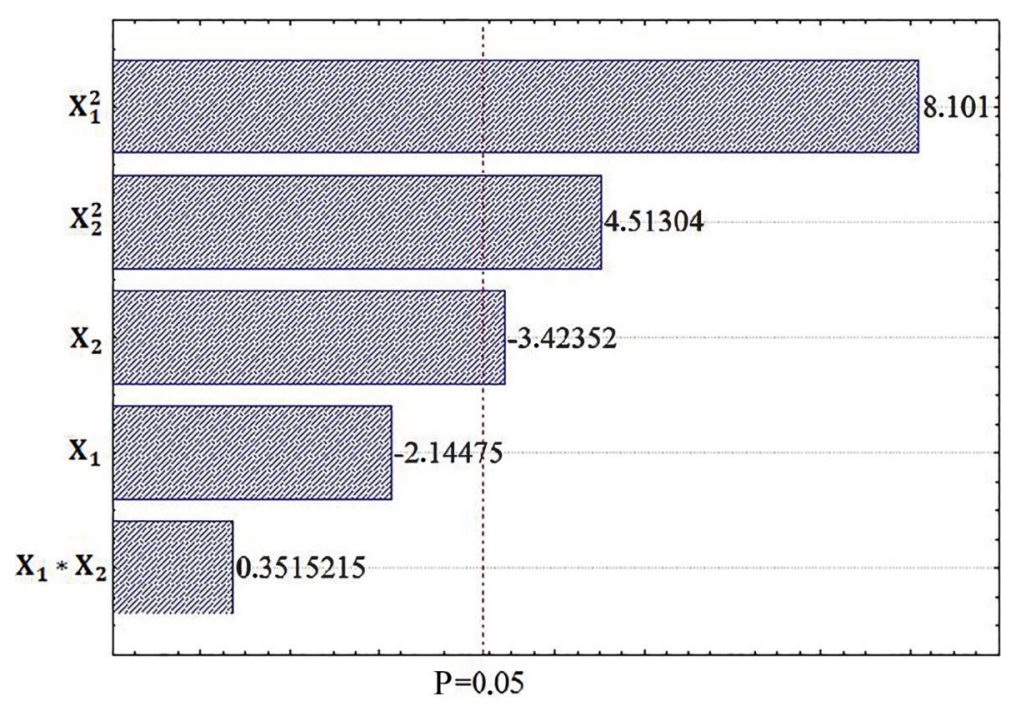

Figure 1. Effects of $\mathrm{pH}\left(\mathrm{X}_{1} \mathrm{X}_{1}^{2}\right)$ and temperature $\left(\mathrm{X}_{2} \mathrm{X}_{2}^{2}\right)$ on biosurfactant surface tension.

and burnt oil, and of $33.72 \mathrm{mN} / \mathrm{m}$ when produced in corn steep liquor and sunflower frying oil.

The aggregation of waste and by-products in media for the production of biosurfactants can minimize environmental impacts and reduce the production costs of biotechnological materials. Wastes and by-products have been used in several studies with different microorganisms to produce biosurfactants including fry waste of soybean oil, pineapple broth, burned sunflower oil, corn steep liquor, soybean oil, glycerol, ground nut oil refinery residue and soybean oil refinery residue, among others $(2,23-27)$.

\section{Growth kinetics and biosurfactant production}

After the establishment of the best conditions for cultivation by the CCRD, the growth kinetics and biosurfactant production were described.

Figure 2 shows the production kinetics of the biosurfactant from Streptomyces sp. DPUA1559 in mineral medium containing $1 \%$ residual soybean oil and $1 \%$ peptone during $120 \mathrm{~h}$ of cultivation. The microorganism exponential phase occurred in the first $24 \mathrm{~h}$, corresponding to the adaptation phase to physical-chemical compositions of the culture medium. The biomass reached $1.26 \mathrm{~g} / \mathrm{L}$ in this phase. The start of stationary growth phase and biosurfactant production occurred after $48 \mathrm{~h}$. The biomass reached $4.81 \mathrm{~g} / \mathrm{L}$ at $96 \mathrm{~h}$. The maximum biomass concentration was around $5.02 \mathrm{~g} / \mathrm{L}$ after $108 \mathrm{~h}$ of fermentation, followed by reduction of the surface tension, so the surface active properties of the biosurfactant were evidenced.

The $\mathrm{pH}$ of the fermentation medium varied between 6.8 and 7.7 in the first $24 \mathrm{~h}$, and remained unchanged (between 8.0 and 8.7) during the rest of the fermentation period. This indicates that the microorganism adapts to the new substrate and promotes the biosynthesis of essential compounds to the growth, producing positive effects in reducing the surface tension and production stability $(24,25)$. According to Rufino et al. (8), each microorganism adapts to a specific $\mathrm{pH}$ for each type of biosurfactant to be produced.

After $120 \mathrm{~h}$, the surface tension was reduced from 60 to $27 \mathrm{mN} / \mathrm{m}$, although the surface tension values were less than $30 \mathrm{mN} / \mathrm{m}$ after $48 \mathrm{~h}$. Silva et al. (28) have reported a reduction in the surface tension to $27.4 \mathrm{mN} / \mathrm{m}$ after $72 \mathrm{~h}$ of cultivation in the biosurfactant production by $P$. aeruginosa UCP0992, while Lima et al. (24) have observed a surface tension around $27.5 \mathrm{mN} / \mathrm{m}$ by a strain of $P$. fluorescens. The biosurfactant production by Streptomyces $s p$. DPUA1559 was observed in the stationary phase, after $96 \mathrm{~h}$, with a yield of around $1.95 \mathrm{~g} / \mathrm{L}$. The full production was $2.24 \mathrm{~g} / \mathrm{L}$ after $108 \mathrm{~h}$ of cultivation.

\section{Emulsification index with different hydrophobic compounds}

The emulsification index was determined using the cell-free broth for different hydrophobic substrates: kerosene, motor oil, motor residual oil, diesel oil and vegetable oils (corn, canola, soybean and sunflower). The cell-free broth showed 38 and $40 \%$ emulsification of diesel and kerosene, respectively, while the emulsification index for motor oil and residual motor oil were respectively 89 and $95 \%$. Silva et al. (28) reported an emulsification value of $53.7 \%$ for diesel, while a value of $50.2 \%$ was found for motor oil for the biosurfactant produced by $P$. aeruginosa.

Emulsification by the biosurfactant from Streptomyces sp. DPUA1559 showed 47, 41, 36, and 30\% for corn oil, soybean oil, canola oil and sunflower oil, respectively. Rufino et al. (8) have observed an emulsification value for motor oil of $78 \%$, while the corn oil was not effectively emulsified by the biosurfactant from Candida lipolytica UCP0998. The biosurfactant produced by Streptomyces $s p$. DPUA1559, in the conditions of this work, showed 


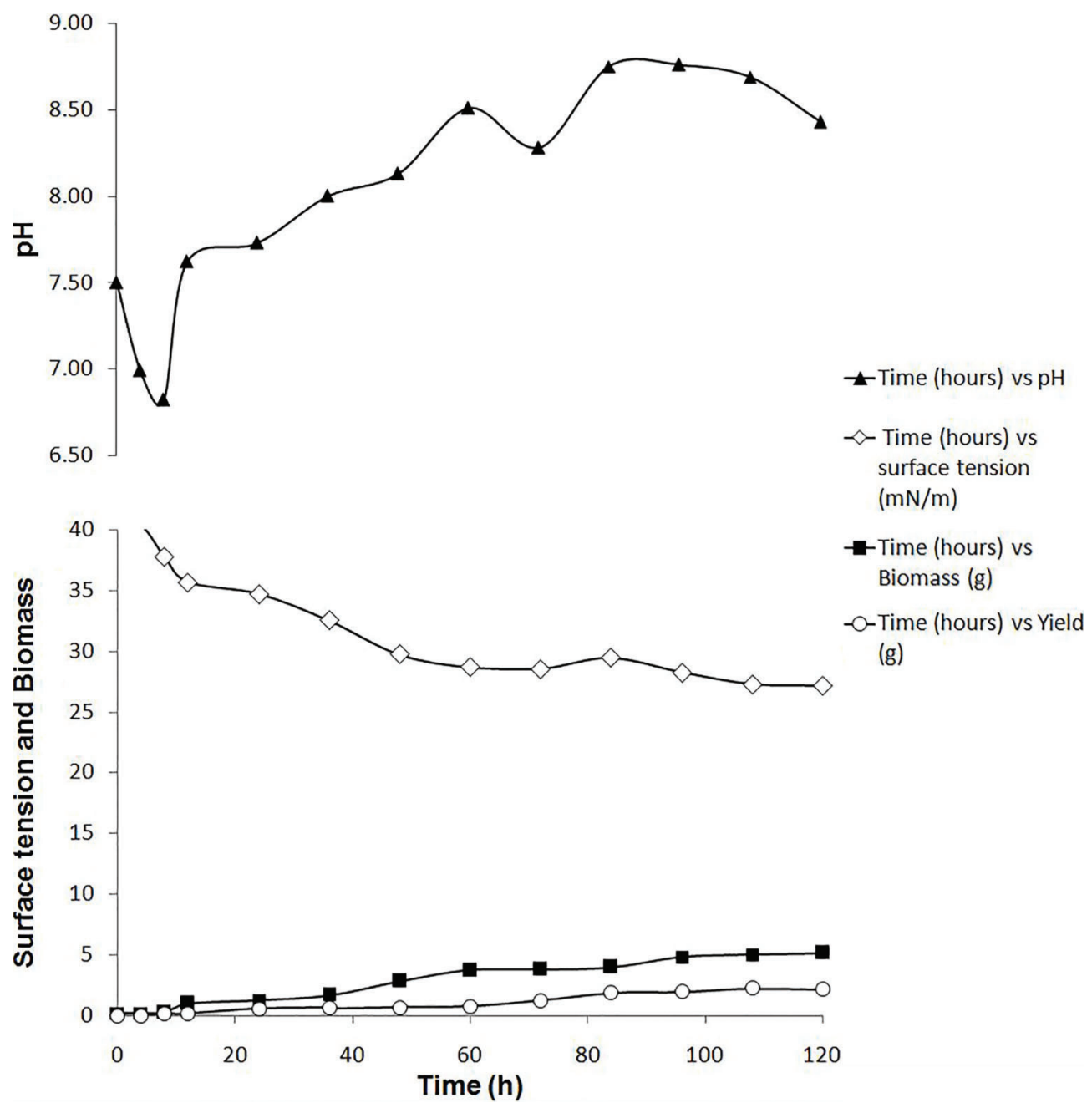

Figure 2. Kinetics of growth, $\mathrm{pH}$, surface tension and biosurfactant production after $120 \mathrm{~h}$ of fermentation.

affinity for hydrophobic compounds tested, acting as surfactant agent and emulsifier.

\section{CMC of the biosurfactant}

Figure 3 represents the CMC of the biosurfactant produced by Streptomyces sp. DPUA1559, which demonstrated a potential to reduce the surface tension from 70 to $33.76 \mathrm{mN} / \mathrm{m}$, corresponding to a CMC of $10 \mathrm{mg} / \mathrm{mL}$. Rufino et al. (8) reported a similar result for the biosurfactant produced by the yeast $C$. lipolytica UCP0998, whose CMC had a value of $10 \mathrm{mg} / \mathrm{mL}$ and a surface tension around $32 \mathrm{mN} / \mathrm{m}$. Superior results of CMC have been obtained for biosurfactants isolated of Streptomyces tendae and Streptomyces sp. B3, whose values were respectively $36 \mathrm{mg} / \mathrm{L}$ and $110 \mathrm{mg} / \mathrm{L}(29,30)$. Gudina et al. (31) reported a CMC of $2.5 \mathrm{mg} / \mathrm{mL}$ of the biosurfactant produced by Lactobacillus paracasei.

A surface tension of $25.42 \mathrm{mN} / \mathrm{m}$ was reported by Chen et al. (32) for the biosurfactant produced from
B. licheniformis TKU004 in a concentration of $350 \mathrm{mg} / \mathrm{L}$, while Sobrinho et al. (33) has reported lower values of CMC for the biosurfactant of C. sphaerica UCP0995 of $0.08 \%$.

\section{Stability of the biosurfactant}

Purification accounts for up to $60 \%$ of the total production cost of biosurfactants. Because of economic considerations in the industry, most biosurfactants would require either whole-cell culture broths or crude preparations. Therefore, the application of the biosurfactant from Streptomyces sp. DPUA1559 in its crude form without prior costly extraction steps was investigated.

Figure 4 shows the influence of $\mathrm{pH}$ on surface tension of the cell-free broth from Streptomyces sp. DPUA1559 grown in soybean frying oil after $96 \mathrm{~h}$ of fermentation.

The results showed that the biosurfactant presented small changes in the values of surface tension when subjected to different $\mathrm{pH}$ values $(4,6,8,10)$ and it remained 
stable at $\mathrm{pH} 2$ and $12(30.23 \pm 0.04 \mathrm{mN} / \mathrm{m})$. The graph shows that the lowest value of surface tension $(27.14 \mathrm{mN} / \mathrm{m})$ was obtained at $\mathrm{pH} 8$, while the highest value was found at $\mathrm{pH} 2(30.26 \mathrm{mN} / \mathrm{m})$. Although the denaturation of protein compounds or increased ionization of the medium may cause the variation of the surface tension to extreme $\mathrm{pH}$ values (34), the graph shows that the biosurfactant had good surface activity in both acidic and basic media. The biosurfactant produced by $C$. lipolytica UCP0988 also presented a similar stability in the environmental conditions of $\mathrm{pH}(2-12)$ (8), while the biosurfactant from $C$. sphaerica UCP0995 was stable at a pH range from 2 to 12 and with lower values of surface tension around $26 \mathrm{mN} / \mathrm{m}$.

Figure 5 shows the effect of temperature on surface tension of the biosurfactant produced by Streptomyces $s p$. DPUA1559. The biomolecule showed resistance to the high and low temperatures studied, presenting thermal

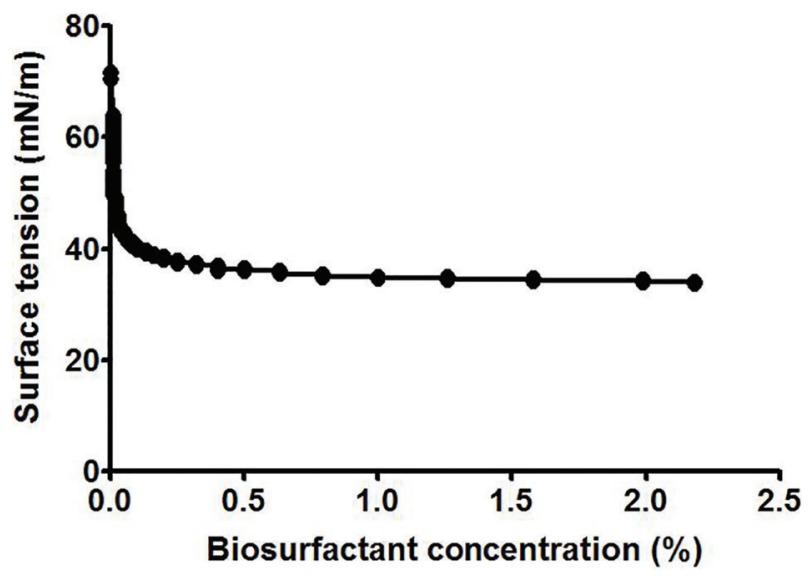

Figure 3. Surface tension and critical micelle concentration of the biosurfactant after $96 \mathrm{~h}$ of fermentation.

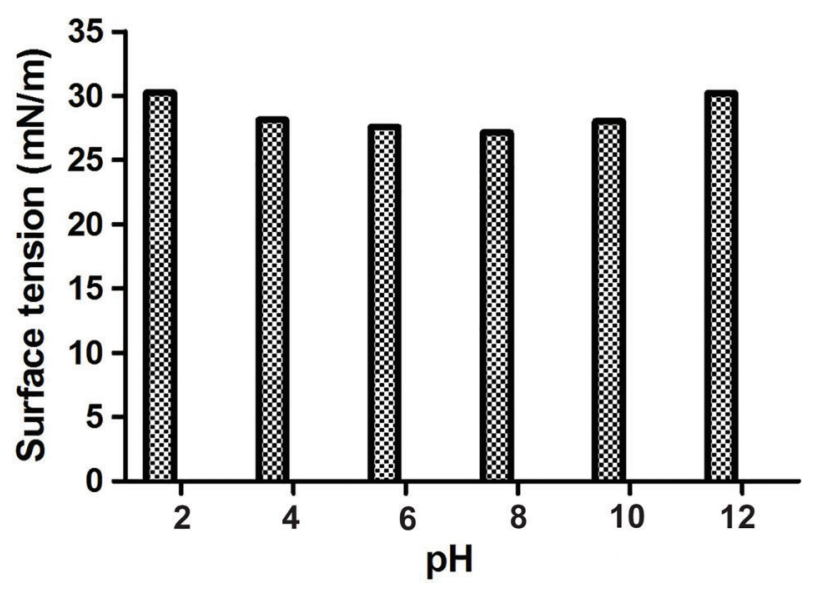

Figure 4. Influence of $\mathrm{pH}$ on the surface tension of the biosurfactant after $96 \mathrm{~h}$ of fermentation. stability of surface tension. The surface tension was stable between $4-80^{\circ} \mathrm{C}$. However, there was a slight increase (29.06 to $30.19 \mathrm{mN} / \mathrm{m}$ ) of surface tension in a temperature range between $100-120^{\circ} \mathrm{C}$. The surface tension in the temperature reported in this study are similar to those described by Khopade et al. (7) for the biosurfactant produced by Streptomyces sp. B3.

Figure 6 illustrates the effect of different $\mathrm{NaCl}(\%)$ concentrations on surface tension of the cell-free broth of Streptomyces sp. DPUA1559. The surface tension of the biosurfactant increased from $0 \%$ until $12 \%$. The lowest value was $30.06 \mathrm{mN} / \mathrm{m}$ and the highest value was $33.38 \mathrm{mN} / \mathrm{m}$. The biosurfactant surface tension was stable when subjected to high concentrations of $\mathrm{NaCl}$, considering that concentrations above $2 \%$ of $\mathrm{NaCl}$ are enough to inhibit the activity of synthetic surfactants (35). Microbial surfactants synthesized by C. lipolityca UCP0988 and C. sphaerica UCP0995 were also stable in different concentrations of $\mathrm{NaCl}$, confirming the results presented in this work $(2,8)$.

\section{Toxicity of the biosurfactant}

The biosurfactant produced by Streptomyces $s p$. DPUA1559 showed no toxicity to the micro-crustacean Artemia salina at concentrations of 50,100 , and $150 \mathrm{~g} / \mathrm{mL}$ based on its CMC of $10 \mathrm{mg} / \mathrm{mL}$. The concentration of 600 $\mathrm{mg} / \mathrm{mL}$ promoted $100 \%$ mortality. The lethal concentration was $300 \mathrm{~g} / \mathrm{mL}$, with $95 \%$ confidence interval, showing $40 \%$ of mortality. According to Saeki et al. (36), the biosurfactant JE1058BS produced by Gordonia sp. also demonstrated low toxicity to two species of marine larvae, Bahia mysidopsis (shrimp) and Menidia beryllina (fish). The biosurfactant produced by the yeast $C$. sphaerica UCP0995 showed no toxicity to the micro-crustacean $A$. salina (2).

Figure 7 represents the phytotoxicity promoted by the biosurfactant from Streptomyces sp. DPUA1559. The concentrations of the biosurfactant to the phytotoxicity

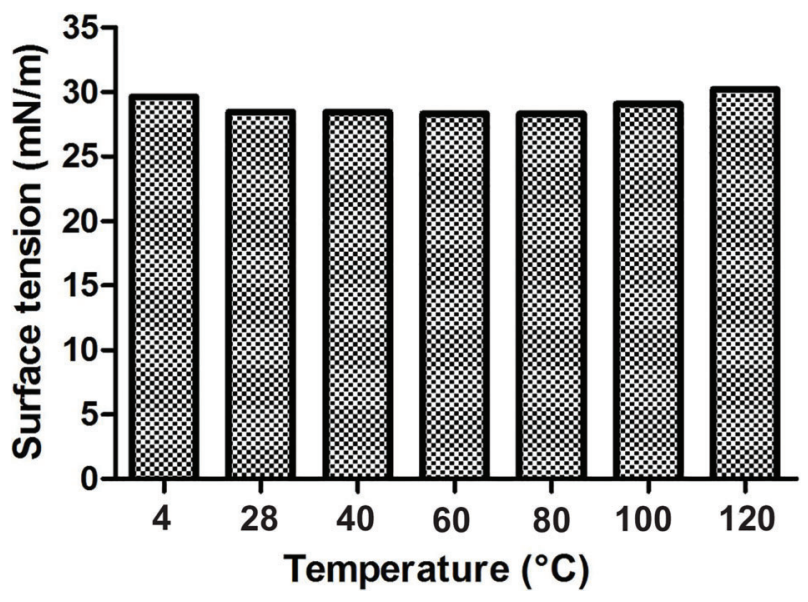

Figure 5. Influence of temperature on the surface tension of the biosurfactant after $96 \mathrm{~h}$ of fermentation. 
tests of 1,5 , and $50 \mathrm{mg} / \mathrm{mL}$ did not display inhibitory effects on seed germination and root elongation after 5 days of incubation.

The germination indexes obtained for seeds of lettuce were 167,110 , and $92 \%$, while for seeds of cabbage were

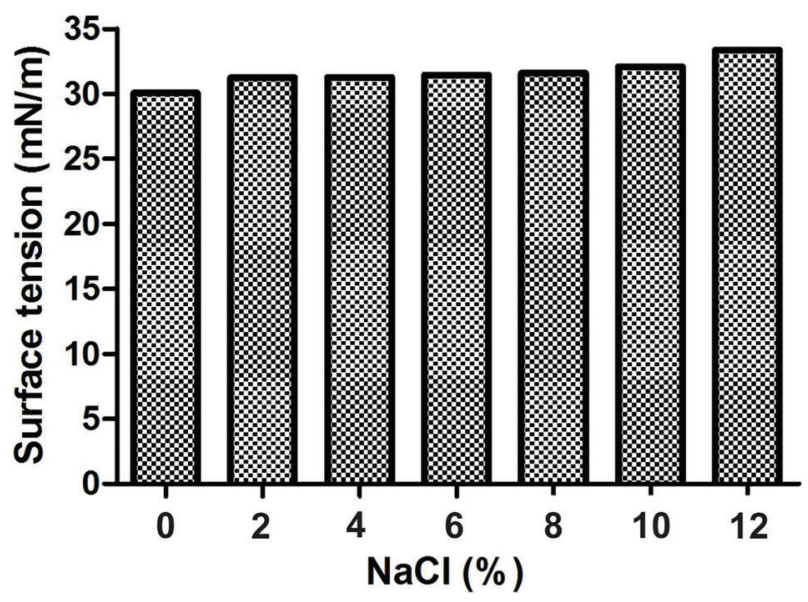

Figure 6. Influence of different sodium chloride concentrations on the surface tension of the biosurfactant after $96 \mathrm{~h}$ of fermentation.

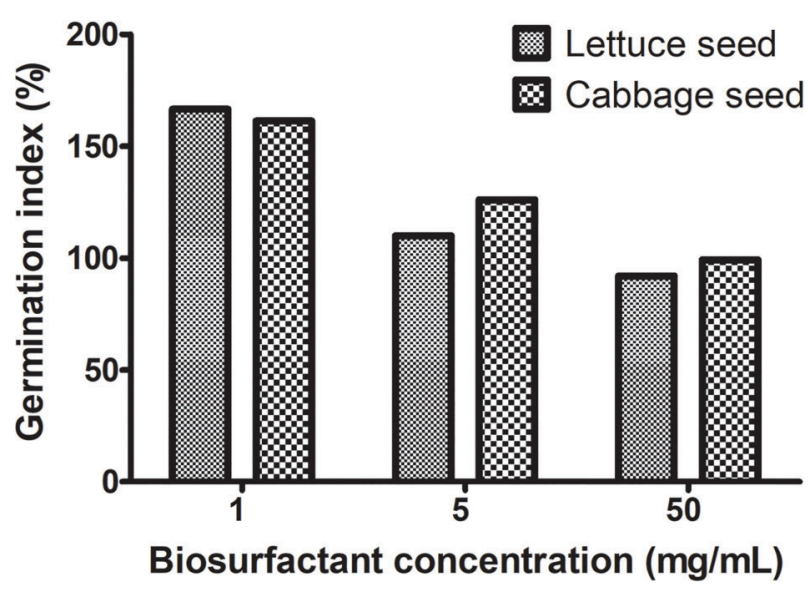

Figure 7. Effect of phytotoxicity of Streptomyces sp. biosurfactant on the seeds of lettuce and cabbage.
162,126 , and $100 \%$, showing high germination, with good correlation between average elongation of root and germination index. The biosurfactants produced by $P$. aeruginosa UCP0992 promoted no toxicity to the seeds of Lactuca sativa $L$. and Brassica oleracea $L$. at concentrations similar to those reported in this work, as the lower concentrations of biosurfactant produced by $C$. sphaerica UCP0995 $(2,28)$.

\section{Characterization of the biosurfactant}

The biosurfactant produced by Streptomyces $s p$. DPUA1559 showed a chemical composition with $20 \%$ of proteins, $38 \%$ of carbohydrates and $12 \%$ of lipids. The protein portion marked with Periodic Acid-Schiff reagent was positive, indicating the presence of glycoproteins.

The biosurfactants isolated from several microorganisms can be lipids, glycolipids, lipopeptides and polysaccharide protein complexes (3). The biochemical composition of the biosurfactant probably depends on the substrates utilized in the culture medium. Rufino et al. (8) have reported that the biosurfactant isolated from C. lipolytica UCP0988 showed $50.0 \%$ of proteins, $8.0 \%$ of carbohydrates and $20.0 \%$ of lipids in the presence of refinery soybean oil. Other results were reported by Thavasi et al. (37), who showed that the biosurfactant of Lactobacillus delbrueckii has a composition $30.0 \%$ of carbohydrates and $70.0 \%$ of lipids. Luna et al. (2) obtained $15.0 \%$ of carbohydrate and $70.0 \%$ of lipid for the biosurfactant of C. Sphaerica UCP0995.

The molecular mass of the biosurfactant from Streptomyces sp. was around $14.3 \mathrm{kDa}$. The molecular characterization of the biosurfactant through the polyacrylamide gel showed a single protein band in the presence of denaturing and reducing conditions, revealing electrophoretic homogeneity. Moreover, the protein band exhibited acidic character.

Table 4 presents the main frequencies of the biosurfactant functional groups analyzed by ATR-FTIR. The spectral analysis of the solubilized biosurfactant in methanol presented intense bands characteristic of some functional groups. The spectra revealed a band at $3295 \mathrm{~cm}^{-1}$, indicating the presence of hydroxyl and a weak band at $2923 \mathrm{~cm}^{-1}$ related to the vibrations of axial deformation $\mathrm{C}-\mathrm{H}$ of $\mathrm{sp}^{3}$ carbons. The low intensity of this signal indicates

Table 4. Characteristic spectral peaks analysis of biosurfactant produced by Streptomyces sp. DPUA1559 by ATR-FTIR.

\begin{tabular}{lc}
\hline Functional groups & Characteristic frequencies $\left(\mathrm{cm}^{-1}\right)$ \\
\hline Confirmed the presence of hydroxyl & 3295 \\
Weak bands related to the vibrations of axial deformation C-H of carbon sp & 2923 \\
Amides and amides II observed due to angular deformation & 1647 and 1559 \\
Aromatic ring axial deformation of C=C & 1454 and 1401 \\
Broadband of axial intensity median of C-O & 1093 \\
Intense band & 620 \\
\hline
\end{tabular}


that there are no long chains of $\mathrm{CH}_{2}$ and $\mathrm{CH}_{3}$ groups in the molecule. Two bands at 1647 and $1559 \mathrm{~cm}^{-1}$ for amides were observed due to the angular deformation of $\mathrm{NH}_{2}$ and $\mathrm{NH}$, known as the amide band II. Bands at 1454 and $1401 \mathrm{~cm}^{-1}$ of axial deformation of $\mathrm{C}=\mathrm{C}$ of aromatic ring were observed and a broad band of medium intensity was observed in $1093 \mathrm{~cm}^{-1}$, characteristic of $\mathrm{C}-\mathrm{O}$ axial deformation relative to primary alcohol. An intense band at $620 \mathrm{~cm}^{-1}$ indicates the frequency associated with the angular deformation for $\mathrm{C}=\mathrm{C}$, as well as the presence of halides such as chlorine, bromine or iodine.

Infrared analysis indicated that the surfactant chemical structure is basically composed of peptides. The chemical profiles obtained by infrared analysis of the biotensoactive isolated and solubilized in water are identical, having only different polarities, basically composed of peptides. Although it presents amphiphilic characteristics, a detailed structural analysis of the biosurfactant is necessary to define its chemical structure.

The strain of Streptomyces sp. DPUA1559 demonstrated potential to produce surfactant molecules and emulsify in the presence of residual soybean oil. A prediction statistical model was important to establish the conditions of $\mathrm{pH}$ and temperature, optimizing the production of the biosurfactant. The molecule showed stability in extreme environmental conditions of $\mathrm{pH}$, temperature and different salt concentrations. The biosurfactant was

\section{References}

1. Luna JM, Rufino RD, Albuquerque CDC, Sarubbo LA, Campos Takaki GM. Economic optimized medium for tensioactive agent production by Candida sphaerica UCP0995 and application in the removal of hydrophobic contaminant from sand. Int J Mol Sci 2011; 12: 2463-2476, doi: 10.3390/ ijms12042463.

2. Luna JM, Rufino RD, Sarubbo LA, Campos Takaki GM. Characterisation, surface properties and biological activity of a biosurfactant produced from industrial waste by Candida sphaerica UCP0995 for application in the petroleum industry. Colloids Surf B Biointerfaces 2013; 102: 202-209, doi: 10.1016/j.colsurfb.2012.08.008.

3. Gudiña EJ, Teixeira JA, Rodrigues LR. Biosurfactants produced by marine microorganisms with therapeutic applications. Mar Drugs 2016; 14: 1-15, doi: 10.3390/md14020038.

4. Bondi CAM, Marks JL, Wroblewski LB, Raatikainen HS, Lenox SR, Gebhardt KE. Human and environmental toxicity of sodium lauryl sulfate (SLS): evidence for safe use in household cleaning products. Environ Health Insights 2015; 9: 27-32, doi: 10.4137/EHI.S31765.

5. Nkadi PO, Merritt TA, Pillers DAM. An overview of pulmonary surfactant in the neonate: genetics, metabolism, and the role of surfactant in health and disease. Mol Genet Metab 2009; 97: 95-101, doi: 10.1016/j.ymgme.2009.01.015.

6. Santos APP, Silva MDS, Costa EVL. Biossurfactantes: uma alternativa para o mercado industrial. Fronteiras $J$ Social Technol Environ Sci 2016; 5: 88-103, doi: 10.21664/ 2238-8869.2016v5i1.p88-103. not toxic to micro-crustacean Artemia salina, and seeds of lettuce (Lactuca sativa L.) and cabbage (Brassica oleracea $L$.). The characterization showed a new surfactant with only one protein band having electrophoretic homogeneity and low molecular weight. The results are promising for a possible application of the biosurfactant in the industrial biotechnological area. Moreover, future investigations must be carried out in order to investigate its applications in the medical area.

\section{Acknowledgments}

We thank the Parasitology Department of the Federal University of Amazonas (Manaus, AM, Brazil) for providing the strain of Streptomyces sp. DPUA1559, the main object of our study. We are grateful to the Research Support Center (CENAPESQ) of Federal Rural University of Pernambuco (UFRPE) and to the Catholic University of Pernambuco (UNICAP) for their technical support. This study received funding from the Brazilian fostering agencies the State of Pernambuco Foundation for Assistance to Science and Technology (FACEPE); the National Council for Scientific and Technological Development (CNPq), the Federal Agency for the Support and Evaluation of Graduate Education (CAPES), and the Research and Development Program of the Brazilian National Electrical Energy Agency (ANEEL).

7. Khopade R, Ren B, Liu X-Y, Mahadik K, Zhang L, Kokare C. Production and characterization of biosurfactant from marine Streptomyces species B3. J Colloid Interface Sci 2012; 367: 311-318, doi: 10.1016/j.jcis.2011.11.009.

8. Rufino RD, Sarubbo LA, Neto BB, Campos-Takaki GM. Experimental design for the production of tensio-active agent by Candida lipolytica. Ind Microbiol Biotechnol 2008; 35: 907-914, doi: 10.1007/s10295-008-0364-3.

9. Quinn PJ, Carter ME, Markey B, Carter GR. Clinical veterinary microbiology. London: Wolfe; 1994.

10. Muth G, Brolle DF, Wohlleben W. Genetics of streptomyces. In: Demain AL, Davies J (Editors). Manual of industrial of microbiology and biotechnology. 2nd edn. Washington: ASM Press; 1999. p 35.

11. Pridham TG, Anderson $P$, Foley $C$, Lindenfelser LA, Hesseltine CW, Benedict RG. A selection of media for maintenance and taxonomic study of Streptomyces. Antibiot Annu 1956-1957; 947-953.

12. Javaheri M, Jenneman GE, Mclnerney MJ, Knapp RM. Anaerobic production of a biosurfactant by Bacillus licheniformis JF-2. Appl Environ Microbiol 1985; 50: 698-700.

13. Cooper DG, Goldenberg BG. Surface active agents from Bacillus species. Appl Environ Microbiol 1987; 53: 224-229.

14. Meyer BN, Ferrigni NR, Putnam JE, Jacobsen LB, Nichols $\mathrm{DE}$, McLaughlin JL. Brine shrimp: a convenient general bioassay for active plant constituents. Planta Med 1982; 45: 31-34, doi: 10.1055/s-2007-971236. 
15. Tiquia SM, Tam NF, Hodgkiss IJ. Effects of composting on phytotoxity of spent pig-manure sawdust litter. Environ Pollut 1996; 93: 249-256, doi: 10.1016/S0269-7491(96) 00052-8.

16. Lowry $\mathrm{OH}$, Rosebrough NJ, Farr AL, Randall RJ. Protein measurement with the folin phenol reagent. $J$ Biol Chem 1951;193: 265-275.

17. DuBois M, Gilles KA, Hamilton JK, Rebers PA, Smith F. Colorimetric method for determination of sugars and related substances. Anal Chem 1956; 28: 350-356, doi: 10.1021/ ac60111a017.

18. Folch J, Lees M, Sloane Stanley GH. A simple method for the isolation and purification of total lipides from animal tissues. J Biol Chem 1957; 226: 497-509.

19. Laemmli UK. Cleavage of structural proteins during the assembly of the head of bacteriophage T4. Nature 1970; 227: 680-685, doi: 10.1038/227680a0.

20. Davis BJ. Disk electrophoresis: method and application to human serum proteins. Annal NY Acad Sci 1964; 121: 404-427, doi: 10.1111/j.1749-6632.1964.tb14213.x.

21. Mulligan $\mathrm{CN}$. Environmental application for biosurfactants. Environ Pollut 2005; 133: 183-198, doi: 10.1016/j.envpol. 2004.06.009.

22. Lima e Silva TA, Luna JM, Moraes Filho MA, Tambourgi EB, Campos Takaki GM. Biosurfactant production by Pseudomonas fluorescens UCP 1514 using corn steep as substrate. Exacta 2010; 8: 19-26, doi: 10.5585/exacta.v8i1.1686

23. Lima CJB, Contiero J. Use of soybean oil fry waste for economical biosurfactant production by isolated Pseudomonas aeruginosa using response surface methodology. Curr Trends Biotechnol Pharm 2009; 3: 162-171.

24. Lima RA, Andrade RFS, Santos LQ, Campos Takaki GM. Biosurfactant production by Pseudomonas fluorescens in pineapple broth (Ananas comosus) with burned sunflower oil and application in removal of petrol derivative. Exacta 2010; 8: 201-210, doi: 10.5585/exacta.v8i3.2251.

25. Rufino RD, Luna JM, Sarubbo LA, Rodrigues LRM, Teixeira JAC, Campos-Takaki GM. Antimicrobial and anti-adhesive potential of a biosurfactant Rufisan produced by Candida lipolytica UCP 0988. Colloids Surf B Biointerfaces 2011; 84: 1-5, doi: 10.1016/j.colsurfb.2010.10.045.

26. Accorsini FR, Mutton MJR, Lemos EGM, Benincasa M. Biosurfactants production by yeasts using soybean oil and glycerol as low cost substrate. Braz J Microbiol 2012; 43: 116-125, doi: 10.1590/S1517-83822012000100013.

27. Rufino RD, Luna JM, Campos-Takaki GM, Sarubbo LA. Characterization and properties of the biosurfactant produced by Candida lipolytica UCP 0988. Electron J Biotechnol 2014; 17: 34-38, doi: 10.1016/j.ejbt.2013.12.006.

28. Silva SNRL, Farias CBB, Rufino RD, Luna JM, Sarubbo LA. Glycerol as substrate for the production of biosurfactant by Pseudomonas aeruginosa UCP0992. Colloids Surf B Biointerfaces 2010; 79: 174-183, doi: 10.1016/j.colsurfb. 2010.03.050.

29. Richter M, Willey JM, SüBmuth R, Jung G, Fiedler HP. Streptofactin, a novel biosurfactant with aerial mycelium inducing activity from Streptomyces tendae Tü 901/8c. FEMS Microbiol Lett 1998; 163: 165-171, doi: 10.1111/j.1574-6968. 1998.tb13041.x.

30. Khopade R, Biao R, Liu X, Mahadik K, Zhang L, Kokare C. Production and stability studies of the biosurfactant isolated from marine Nocardiopsis sp. B4. Desalination 2012; 285: 198-204, doi: 10.1016/j.desal.2011.10.002.

31. Gudina EJ, Teixeira JA, Rodrigues LR. Isolation and functional characterization of a biosurfactant produced by Lactobacillus paracasei. Colloids Surf B Biointerfaces 2010; 76: 298-304, doi: 10.1016/j.colsurfb.2009.11.008.

32. Chen YC, Chiang TJ, Liang TW, Wang IL, Wang SL. Reclamation of squid pen by Bacillus licheniformis TKU004 for the production of thermally stable and antimicrobial biosurfactant. Biocatal Agric Biotechnol 2012; 1: 62-69, doi: 10.1016/j.bcab.2011.08.010.

33. Sobrinho HBS, Rufino RD, Luna JM, Salgueiro AA, Campos-Takaki GM, Leite LFC, et al. Utilization of two agroindustrial by-products for the production of a surfactant by Candida sphaerica UCP0995. Process Biochem 2008; 43: 912-917, doi: 10.1016/j.procbio.2008.04.013.

34. Ghurye GL, Vipulanandan C, Willson RC. A practical approach to biossurfactant production using nonaseptic fermentation of mixed cultures. Biotechnol Bioeng 1994; 44 : 661-666, doi: 10.1002/bit.260440514.

35. Kim SH, Lim EJ, Lee SO, Lee JD, Lee TH. Purification and characterization of biosurfactants from Nocardia sp. L-417. Biotechnol Appl Biochem 2000; 31: 249-253, doi: 10.1042/ BA19990111.

36. Saeki H, Sasaki M, Komatsu K, Miura A, Matsuda H. Oil spill remediation by using the remediation agent JE1058BS that contains a biosurfactant produced by Gordonia sp. Strain JE-1058. Bioresour Technol 2008; 100: 572-577, doi: 10.1016/j.biortech.2008.06.046.

37. Thavasi R, Jayalakshmi S, Banat IM. Application of biossrfactant produced from peanut oil cake by Lactobacillus delbruckii in biodegradation of crude oil. Bioresour Technol 2011; 102: 3366-3372, doi: 10.1016/j.biortech.2010.11.071. 